\title{
HIV Envelope-Specific Antibody and Vaccine Efficacy
}

\author{
Egidio Brocca-Cofano, Peng Xiao and Marjorie Robert-Guroff \\ Vaccine Branch, National Cancer Institute, Bethesda,
}

USA

\section{Introduction}

Following transmission, the human immunodeficiency virus (HIV) initiates persistent infection by integrating into the genome of host cells. To date it has not been possible to clear these cells by anti-viral or immune therapy, during either active or latent infection. This makes design of an efficacious HIV vaccine exceedingly difficult, since complete prevention of infection, or "sterilizing immunity", is required. As cellular immunity targets already infected cells, humoral immune responses which can prevent initial infection by means of anti-envelope neutralizing antibodies have been a prime focus of vaccine development. In proof of concept studies, passive administration of potent neutralizing antibodies has prevented infection of non-human primates by intravenous and mucosal routes (Mascola et al., 1999; Baba et al., 2000; Mascola et al., 2000; Parren et al., 2001), validating the research focus on neutralizing antibody induction. However, the task of designing an envelope vaccine is complicated by the extreme variability among HIV isolates, the propensity for neutralization escape resulting from immune pressure exerted by induced antibodies, conformational features of the HIV envelope which make immunogen design difficult, and additional envelope characteristics which effectively hide areas of vulnerability which might ordinarily be antibody targets. There are several excellent recent reviews covering the issue of broadly neutralizing antibodies (Mascola \& Montefiori, 2010; Walker \& Burton, 2010; Zolla-Pazner \& Cardozo, 2010; McElrath \& Haynes, 2010) and it is not the intent of this review to reproduce that information. Rather, we will briefly summarize some of the salient issues and approaches, and then discuss more extensively non-neutralizing anti-envelope antibodies.

Broadly neutralizing antibodies are difficult to elicit by vaccination. But the HIV envelope protein is quite immunogenic, and an array of non-neutralizing antibodies is induced by both natural infection and vaccination. Through use of sensitive new methods, these antibodies have exhibited several functional activities associated with protection. In serum these include antibody-dependent cellular cytotoxicity (ADCC) (Weinhold, 1990) and antibody-dependent cell mediated viral inhibition (ADCVI) (Forthal et al., 2006). Secretory antibodies have also been associated with protection via mechanisms such as transcytosis inhibition (Bomsel et al., 1998). Augmented by high avidity and recall memory responses which improve their efficacy, these antibody activities can contribute in varying degrees to vaccine-induced protective efficacy. The main thrust of this review will be to examine these 
non-neutralizing antibody responses in HIV and SIV infection and following vaccination, to describe how they may contribute to protection, and to summarize their potential utility amidst the array of additional immune protective mechanisms available to the host, including innate, cellular, and mucosal immunity.

\section{Neutralizing antibodies}

The variability of the HIV envelope is notorious. The envelope exhibits a $30 \%$ difference in amino acid sequence between the 9 clades designated $\mathrm{A}-\mathrm{K}$, omitting $\mathrm{E}$ and I (Korber et al., 2001). Envelope diversity within clades can be as high as 20\% (Mascola \& Montefiori, 2010). Therefore the goal of eliciting anti-envelope antibodies able to broadly recognize and protect against this spectrum of isolates is daunting. In fact it is difficult to induce broadly neutralizing antibodies by vaccination. Most that arise are relatively weak and only able to neutralize the most sensitive or easy to neutralize "Tier I" isolates (Mascola et al., 2005; Seaman et al., 2010). Yet recent publications document development of cross-reactive neutralizing antibodies during HIV infection (Sather et al., 2009) with 20 to $34 \%$ of HIV-infected individuals possessing significant breadth (Simek et al., 2009; Doria-Rose et al., 2010). That vaccine induction of broadly neutralizing antibodies is a realistic goal is also illustrated by the isolation of a handful of naturally elicited antibodies that recognize a wide spectrum of HIV isolates. These include b12, an monoclonal antibody selected by random reassortment of a phage library which recognizes the CD4 binding site of the HIV envelope (Burton et al., 1994); 2G12, a monoclonal antibody that recognizes carbohydrate moieties (Trkola et al., 1996) on the silent face of the envelope; and monoclonal antibodies 2F5 and 4E10 that target the membrane-proximal external region (MPER) of the viral envelope transmembrane protein (Muster et al., 1993; Zwick et al., 2001). Additionally, the V3 region of the external envelope protein gp120, originally believed to elicit only type-specific neutralizing antibodies, has been shown to elicit broader responses. A panel of V3 monoclonal antibodies including 447-52D was recently reported to exhibit significant cross-clade neutralizing activity (Hioe et al., 2010). The basis for this breadth may be the conserved structural elements in the V3 loop which provide for its essential function as part of the binding region to chemokine co-receptors and which outweigh the inherent variability of the amino acid sequence in importance (Almond et al., 2010; Jiang et al., 2010). Portions of the V3 and V2 loops comprise a novel quaternary epitope, recognized only as part of the native trimer. Monoclonal antibody 2909, the first such described human antibody, is potent but relatively strain specific (Gorny et al., 2005). In contrast, the recently identified monoclonals PG9 and PG16 (Walker et al., 2009) also recognize quarternary epitopes, but differ by exhibiting great neutralization breadth, attributed to dependence on an asparagine-linked carbohydrate moiety at residue 160 in the V2 loop. The 2909 antibody recognizes a lysine at this position (Zolla-Pazner \& Cardozo, 2010). New methods of high-throughput monoclonal antibody cloning and screening have facilitated isolation of several additional broadly neutralizing antibodies (Scheid et al., 2009; Corti et al., 2010). To date VRC01, a CD4 binding site antibody, has shown the greatest breadth, neutralizing $91 \%$ of tested HIV isolates, representative of all major HIV clades $(\mathrm{Wu}$ et al., 2010). Structural knowledge of the HIV envelope, computer-assisted protein design, and state-of-the-art methods for memory B cell sorting and single cell PCR facilitated its isolation. It is hoped that similar new methodologies can lead to design of an appropriate vaccine component able to elicit neutralizing antibody breadth. 


\subsection{Development of neutralizing antibodies in natural infection}

While a significant percentage of HIV-infected individuals with chronic disease have a degree of neutralizing antibody breadth, a much smaller percentage are able to neutralize across all HIV clades (Simek et al., 2009). Long-term non-progressors have rather poor neutralizing antibody responses. Rather potent neutralizing activity seems to require a lengthy time period of sustained viremia and development of strong binding avidity, suggesting that antigen persistence and antibody maturation are needed for development of a broad response (Sather et al., 2009). Neutralizing antibodies develop very slowly in HIVinfected individuals. Antibodies with specificity for gp41 appear first at around 13 days post-infection and anti-gp120 antibodies at around day 28 (Tomaras et al., 2008). However, neutralizing antibodies appear later, usually months after infection, and thus do not appear to control viremia (Aasa-Chapman et al., 2004; Gray et al., 2007). This slow development reflects, at least in part, the same obstacles facing vaccine-induction of a neutralizing antibody response: conformational and carbohydrate masking of critical epitopes; homology of some epitopes with self proteins, leading to polyreactive antibodies that are subject to immune tolerance; and envelope variability leading to immune selective pressure and viral escape (McElrath and Haynes, 2010). Later in the course of disease, loss of CD4 help and B cell dysfunction exacerbates the poor neutralizing antibody development (Alter and Moody, 2010).

\subsection{Improved envelope immunogen design}

In addition to improved envelope design based on increasing knowledge of the structure of the HIV envelope, other approaches have attempted to better expose critical conserved epitopes on envelope immunogens. These have included deletion of variable loops to expose otherwise hidden regions of the envelope; alteration of glycosylation patterns to prevent masking; preparation of trimeric forms of the envelope to mimic the natural structure on the surface of the virion, and introduction of critical epitopes on other scaffolds for better presentation to the immune system (Hu and Stamatatos, 2007). These alterations have had varying degrees of success, although none has induced the breadth and potency of neutralizing antibody response needed for a highly effective vaccine. It is hoped that continued improvements in envelope immunogens fostered by greater knowledge of envelope structure and understanding of the natural process of broadly neutralizing antibody induction will achieve the desired goal.

\section{Non-neutralizing antibodies}

The RV144 phase III trial in Thailand which assessed an ALVAC-recombinant prime/Env protein boost regimen, showed only modest efficacy, protecting $31 \%$ of vaccinated individuals in the intent-to-treat group (Rerks-Ngarm et al., 2009). Nevertheless, this outcome provided the first evidence that development of a safe and effective preventive HIV vaccine is possible. This study also highlighted the need to better understand immune correlates of protection associated with decreased HIV acquisition. The RV144 vaccine components have induced a broad constellation of immune responses, including T-cell-line adapted neutralizing antibody (Nitayaphan et al., 2004), antibody-dependent cell-mediated cytotoxicity (Karnasuta et al., 2005), and CD4+ and CD8+ T cell responses, but clear immune correlates have not been defined. Currently in order to combat the extensive genomic diversity of HIV both strong cellular and humoral immune responses are believed necessary 
for a successful vaccine (Amanna \& Slifka, 2010; Benmira et al., 2010). However, as strong cellular immunity was not elicited in the majority of RV144 vaccinees, humoral immunity is believed to have contributed to the protection against HIV acquisition. As the vaccine regimen did not elicit antibodies able to neutralize primary HIV isolates, the focus of research has shifted to the potential for non-neutralizing antibodies to mediate protection. Neutralizing antibodies are able to prevent infection of susceptible cells; however, once a cell is infected it is difficult to imagine a role for neutralizing antibodies (Battle-Miller et al., 2002). Other antibody functions such as ADCC and ADCVI working together with innate effector cells provide a means to target and kill virus infected cells (Fig. 1A). Such mechanisms could control or possibly eradicate the small foci of infected cells that form in the lamina propria after viral transmission and prior to systemic spread of the virus (Fig. 1B; Haase, 2005).

\subsection{ADCC}

ADCC bridges innate and adaptive immunity. It involves effector cells able to mediate cell lysis, target cells expressing cell surface antigen, and specific antibody that recognizes the cell surface antigen and activates effector cells via interaction with Fc receptors. The interaction between the Fc domain of the antibody and the corresponding receptor on effector cells triggers a series of events that lead to the destruction of the infected cell via cytotoxic granules (perforin, granzyme) or a death-receptor-dependent pathway (Fas/Fas ligand; TNF/TNFR) (de Saint Basile et al., 2010; Chavez-Galan et al., 2009).

Most ADCC responses described in the literature are directed against the envelope protein (Env) (Ahmad \& Menezes, 1996; Baum et al., 1996; Alsmadi \& Tilley, 1998), although Nef (Yamada et al., 2004) and Tat (Florese et al., 2009) have also been shown to be ADCC targets. Additionally, a recent study in chronically infected subjects reported that Pol is an ADCC target, but this Pol-specific ADCC activity did not correlate with delayed HIV progression (Isitman et al., 2010). Moreover, the pol gene encodes internal proteins, so it is possible that the Pol-specific ADCC activity observed was targeting by-stander cells that had scavenged dead-cell debris. Despite the potential efficacy of ADCC, little is known about specific epitopes recognized by antibodies able to mediate ADCC. Epitopes recognized by both antiEnv and anti-Nef antibodies that mediate ADCC have been described (Alsmadi et al., 1997; Yamada et al., 2004; Los Alamos National Laboratory Molecular Immunology Database). As discussed below, anti-Env antibodies that mediate ADCC have been associated with protection, however, whether anti-Nef or anti-Tat antibodies have an impact on natural infection is not known.

Effector cells that mediate ADCC are not major histocompatibility complex restricted, and multiple subpopulations of peripheral blood mononuclear cells (PBMCs) are involved in mediating ADCC function. NK cells, $\gamma \delta$ T cells, neutrophils, monocytes, and macrophages all express the Fc receptor that can engage antibodies (Forthal \& Moog, 2009). A large number of these cells are always present in peripheral tissues, in contrast to memory B and $\mathrm{T}$ cells in lymphoid tissue which require activation for neutralizing antibody or $\mathrm{T}$ cell functions. Since HIV infection rapidly spreads during the first 2 weeks after transmission, the significant time advantage provided, for example, by pre-existing vaccine-elicited antibody and Fc receptor-bearing cells, may facilitate better control of viremia. IgG1 and IgG3 are the most common IgG isotypes to mediate ADCC via strong interaction with the Fc-binding receptor CD16/FcyRIII expressed mainly on NK cells (Niwa et al., 2005). 
Traditionally, ADCC killing was assessed using assays in which target cells were labeled with radioactive isotopes such as ${ }^{51}$ Chromium. Disadvantages of this method include difficulty labeling certain cell types, low assay sensitivity and high spontaneous chromium release resulting in high background values (Volgmann et al., 1989). Several flow cytometrybased alternatives have recently circumvented the problems associated with radioactive labeling of target cells in cytotoxicity assays (Wilkinson et al., 2001; Gomez-Roman et al., 2006a; Stratov et al., 2008; Chung et al., 2009). These assays have provided greater ease of use and importantly greater sensitivity, facilitating investigation of the role of ADCC activity in natural infection and vaccine-induced protection.

\subsubsection{HIV-specific ADCC responses in natural infection}

Over the past 20 years, the dogma that $\mathrm{T}$ cells and neutralizing antibodies are protective immune correlates for many vaccines led to lack of interest in the ADCC mechanism. However the gradual accumulation of evidence from natural infection and vaccine studies supporting a protective role for ADCC has stimulated studies of this immune response. A number of early studies documented the induction of ADCC antibodies during HIV infection (Lyerly et al., 1987; Rook et al., 1987; Ojo-amaize et al., 1987). A potential role for ADCC in modulating the course of HIV infection was eventually suggested based on studies showing an inverse association between ADCC antibody levels and clinical stage of the disease. Baum et al, (1996) presented strong evidence that higher titers of antibodies mediating ADCC correlated with a successful host defense against HIV-1, and Forthal et al., (2001a) reported an inverse association between ADCC activity and plasma viremia. Higher ADCC activity has also been correlated with slower disease progression in children (Ljunggren et al., 1990; Broliden et al., 1993). More recently, ADCC activity has been demonstrated in cervical lavage fluids of HIV-infected women (Battle-Miller et al., 2002), and associated with lower genital HIV RNA loads (Nag et al., 2004). Elite controllers also have higher ADCC antibody titers than viremic individuals, whereas neutralizing antibody activity tends to be higher in viremic individuals (Lambotte et al., 2009). Nevertheless, not all studies have concluded that ADCC plays a role in protective efficacy (Dalgleish et al., 1990; Lifson et al., 1991; Chuenchitra et al., 2003). The conflicting results reflect the complexity of the virus-host interaction and elements that contribute to the ADCC response, including the integrity of the host immune system, extent of viremia, level and affinity of antibodies induced, and functionality of effector cells.

\subsubsection{ADCC responses in non-human primate models}

Non-human primate studies have stimulated interest in the ADCC mechanism and its role in protective efficacy. ADCC activity has been correlated with delayed disease progression in SIV infected macaques (Banks et al., 2002). Additional convincing evidence has come from pre-clinical vaccine studies. A replicating adenovirus type 5 host range mutant (Ad5hr)-SIV recombinant prime/SIV gp120 protein boost regimen was shown to elicit potent protection against an intrarectal $S_{V} V_{\text {mac251 }}$ challenge (Patterson et al., 2004). The

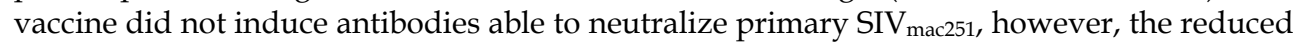
acute viremia was significantly correlated with anti-envelope binding antibodies that

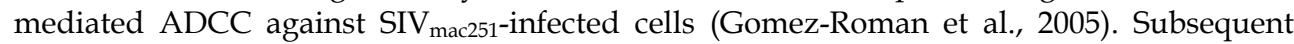
studies, one involving a comparison of Ad5hr-SIV recombinant priming via the upper respiratory tract versus the oral route followed by SIV gp120 boosting and SIV $_{\text {mac251 }}$ 
challenge, and another involving a comparison of Ad5hr-recombinant priming with and without subsequent envelope protein boosting followed by challenge with the chimeric virus $\mathrm{SHIV}_{89.6 \mathrm{P}}$, again showed significant correlations of ADCC activity with reduced acute viremia (Hidajat et al., 2009; Xiao et al., 2010). The latter study also revealed a correlation of ADCC activity with reduced chronic viremia. The importance of antibody maturation in induction of the functional antibody responses was indicated by the significant correlation of ADCC-mediating antibodies with binding antibody avidity.

The non-human primate model provides a good mimic for exploration of vaccine strategies and immune mechanisms. For example, passive antibody transfer studies can directly explore the ability of antibodies to mediate protection. Binley et al. (2000) observed that passive infusion of IgG to rapid and normal progressor SIV $_{\text {mac251 }}$ infected animals caused small and transient reductions in plasma viremia by a mechanism that was inconsistent with virus neutralization but which could have been effector cell mediated, implicating ADCC. In contrast, infusion of IgG possessing high titers of anti-Env antibodies able to mediate ADCC had no effect on viral loads following two sequential oral challenges of neonatel macaques with SIV $_{\text {mac251 }}$ (Florese et al., 2006). In both these studies, high viral loads may have contributed to negligible protective effects. Further, the neonatal macaque study may have been compromised by low levels and poorly functioning effector cells in the baby animals. An improved experimental design using repetitive low dose challenge might yield more significant results.

Passive transfer of monoclonal antibodies has proven more informative in elucidating mechanisms of antibody-mediated protection. An elegant study by Hessell et al. (2007) using the neutralizing b12 monoclonal antibody and a mutant unable to bind the Fc receptor and complement, showed that protection from a SHIV $\mathrm{SF} 162 \mathrm{P} 3_{3}$ challenge mediated by the b12 antibody was in part due to Fc-mediated effects. A follow-on study using low-titered b12, mutant antibody, and low-dose repeated $\mathrm{SHIV}_{\mathrm{SF} 162 \mathrm{P} 3}$ challenge, supported a contribution of effector function to the delayed acquisition observed (Hessell et al., 2009).

As illustrated by the b12 monoclonal, neutralizing antibodies may also mediate ADCC activity via their FC domain. However, all ADCC mediating antibodies do not necessarily possess neutralizing activity. A neutralizing antibody must target a specific region of the viral envelope, whereas antibodies that mediate ADCC are required only to recognize an exposed target epitope on the surface of the infected cell. Antibodies elicited in chimpanzees to an HIV clade B immunization regimen were able to mediate ADCC killing of clade A, B, C, and AE env-expressing target cells (Gomez-Roman et al., 2006). Therefore, in addition to the ability to rapidly respond, the ADCC effector mechanism can provide the breadth of antibody recognition believed necessary for protective efficacy.

The extent to which the ADCC mechanism contributes to vaccine-induced protection is not yet clarified. A definitive conclusion will perhaps come from immune correlates identified in human clinical vaccine trials. To date only a few such trials have evaluated ADCC activity. Goepfert et al. (2007) reported that Env-specific ADCC activity, correlated with binding antibodies, was detected in most individuals that received a candidate AIDS vaccine containing gp120. Further, as mentioned above, a phase II human trial in Thailand has shown induction of ADCC mediating antibodies (Karnasuta et al., 2005). The role of these antibodies in the protection against HIV acquisition seen in the RV144 trial which used similar immunogens is currently being actively explored. 


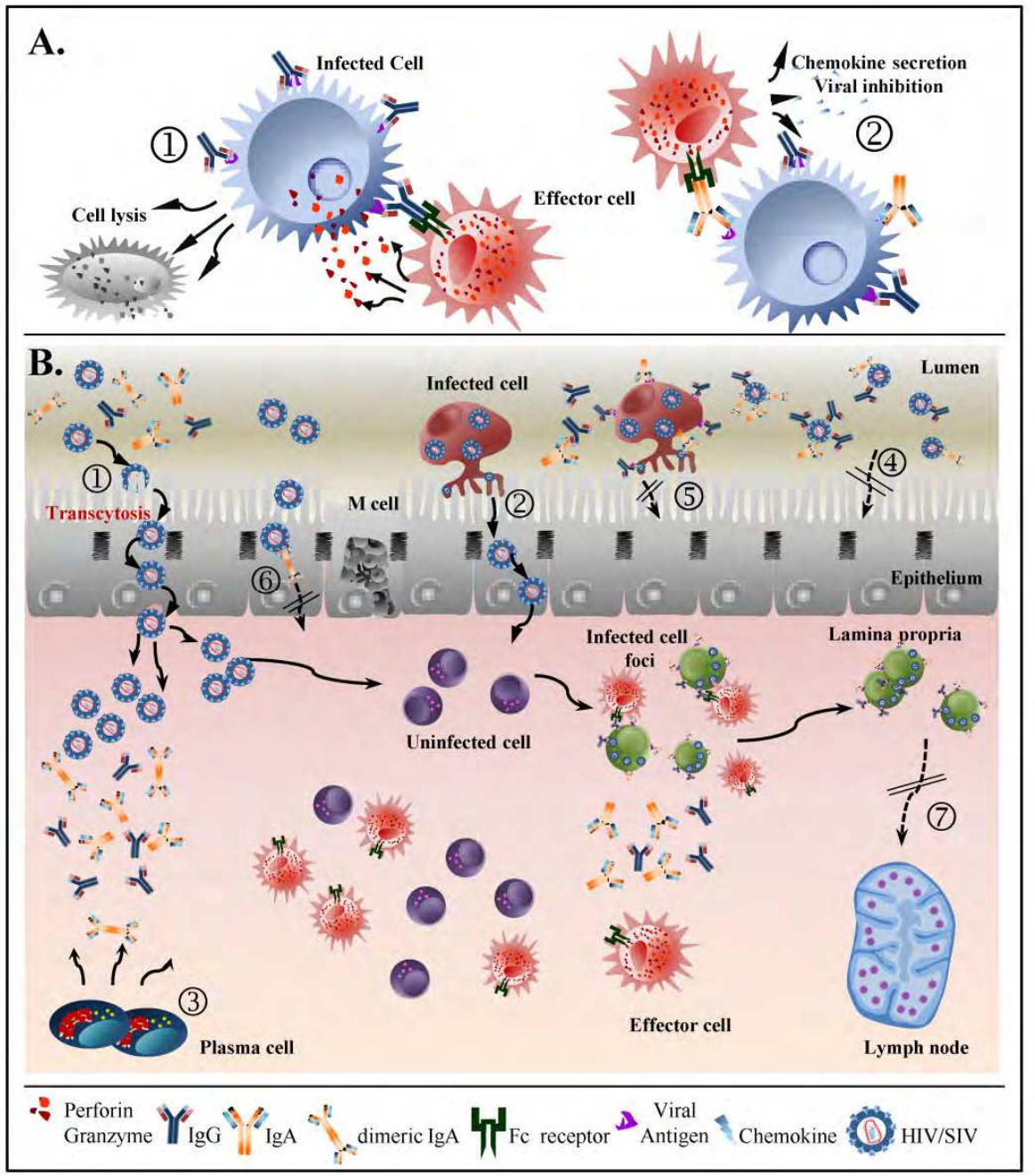

Fig. 1. Control of viral infection by non-neutralizing antibodies. A. ADCC and ADCVI. (1)Fc receptors on effector cells recognize the Fc domain of antibody bound to antigen on infected cells, inducing release of cytotoxic granules and cell lysis via ADCC. (2) Activation of effector cells may lead to production of chemokines and cytokines and viral inhibition by ADCVI. B. A mucosal surface with a single layer of columnar epithelium. Viral transmission may occur by transcytosis of cell-free (1) or cell-associated virus (2). T cells,

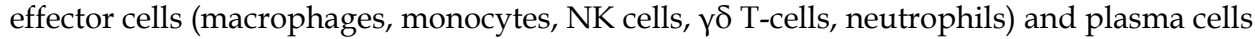
are present in the lamina propria. Mucosal antibodies, secreted by plasma cells (3), may block infection by neutralizing virus (4), or by blocking transcytosis of cell-associated (5) or cell-free virus (6). Antibodies can mediate ADCC and ADCVI to eradicate or control infected cell foci, blocking dissemination of virus to lymph nodes (7). 


\subsection{ADCVI}

Like ADCC, ADCVI requires antibody that forms a bridge between an infected target cell and an FcyR-bearing effector cell (Forthal et al., 2001). However, ADCVI is a broader activity not restricted to target cell lysis, as with ADCC. Rather it encompasses several mechanisms by which viral replication following target cell infection is inhibited. These may include ADCC activity, but also noncytolytic mechanisms of virus control, such as secretion of inhibitory chemokines (Fig. 1A), or FcyR-mediated phagocytosis of immune complexes. The readout in ADCVI assays is the percentage of virus inhibition due to effector cells together with a test antibody relative to a negative control antibody. This biological endpoint allows assessment of ADCVI against any lentiviral strain able to infect cells. As the ADCVI assay uses heat-inactivated serum, complement activities do not play a role (Forthal \& Landucci, 1998). Overall, ADCVI is a measure of the combined ability of antibody and effector cells to inhibit the spread of virus infection (Forthal et al., 2001; Forthal \& Moog, 2009). Both polyclonal and monoclonal antibodies can mediate ADCVI. Intact IgG, not just the $F\left(a b^{\prime}\right) 2$ portion is required (Forthal et al., 2006), emphasizing the importance of Fc-Fc receptor interactions in mediating the functional activity.

\subsubsection{ADCVI during HIV infection}

ADCVI has been associated with reduction in viremia during HIV infection. In HIV-infected individuals, systemic non-neutralizing antibodies appear early during acute infection, generally before a neutralizing antibody response (Sawyer et al., 1990). Not surprisingly, in individuals with acute HIV infection, non-neutralizing ADCVI antibodies appeared as early as the first week after onset of symptoms or the first month after HIV exposure (Forthal et al., 2001). ADCVI activity became more potent as the viral load fell (in the absence of antiretroviral therapy), resulting in an inverse relationship between ADCVI activity and acute plasma viremia, suggesting a protective effect. Importantly, ADCVI antibodies appeared to be broadly reactive with different HIV strains. The demonstration of an association between non-neutralizing but functional antibodies able to mediate ADCVI activities and protection is noteworthy and timely, in view of the recent outcome of the RV144 phase IIb vaccine trial in Thailand as discussed above. A previous study of serum samples from the Vax004 trial which evaluated gp120 vaccines similar to those used for boosting in RV144 revealed an inverse correlation between the HIV infection rate of vaccinated individuals and vaccine-elicited ADCVI antibody activity (Forthal et al., 2007). Although this trial did not result in protection, the results support the hypothesis that similar functional antibody activities may have contributed to protection in the RV144 trial. Taken together, these observations have renewed interest in defining the mechanisms of Fc $\mathrm{R}$-mediated protection by ADCC and ADCVI.

\subsubsection{ADCVI in rhesus macaque models}

In support of a protective role for ADCVI, significant correlations between ADCVI activity mediated by vaccine-induced antibodies and decreased acute viremia have been reported in both SIV and SHIV rhesus macaque models (Florese et al., 2009; Hidajat et al., 2009; Xiao et al., 2010). Further, passive infusion of anti-SIV immune serum with strong ADCVI activity to newborn rhesus macaques prevented infection from an oral SIV $_{\text {mac251 }}$ challenge (Forthal et al., 2006). A recent study showed that vaccine-elicited antibody mediated ADCVI activity that was recalled 4 weeks post-challenge. This post-challenge activity was correlated with 
reduced chronic phase viremia (Xiao et al., 2010) suggesting a broader role for ADCVI in controlling viral replication over the course of disease rather than impacting only early posttransmission viral spread. In this same study, a negative correlation between ADCVI activity 4 weeks post-challenge and neutralizing antibody titer 8 weeks post challenge was observed which became progressively weaker over time, and disappeared by 24 weeks postchallenge. The ADCVI assay evaluates viral inhibition in the presence of serum plus effector cells, and subtracts inhibition observed with serum in the absence of effector cells. This latter inhibition is attributed to neutralizing antibody. Therefore, the inverse correlation between the two activities might indicate that both neutralizing and non-neutralizing antibodies were mediating ADCVI. Neutralizing monoclonal antibodies are known to mediate ADCVI activity (Hessell et al., 2007). Development of de novo neutralizing antibody depends on the presence of sufficient viral antigen to drive the antibody response. The inverse relationship between ADCVI and the more slowly developing neutralizing antibody may reflect control of viremia by ADCVI and/or other immune mechanisms at the expense of strong neutralizing antibody induction due to a reduced viral burden. The complexity of the in vivo situation makes the relationships between functional antibody activities and viral burden difficult to resolve.

\section{Secretory antibody}

Mucosal surfaces are the major site for HIV entry. Therefore, an effective HIV vaccine may require the presence of antibodies able to prevent infection at mucosal sites. IgA antibodies are the most prevalent at mucosal surfaces, and might contribute to protection by one or more mechanisms including classical neutralization, but also non-neutralizing activities such as immune exclusion involving mucus entrapment and clearance, ADCC discussed above, and inhibition of HIV transcytosis across the epithelial cell barrier (Fig. 1B; Kozlowski and Neutra, 2003). Study of HIV-exposed but uninfected individuals (so called highly-exposed, seronegative; or HEPS), has shown the presence of functional HIV-specific IgA at mucosal surfaces of these individuals (Miyazawa et al., 2009; Lopalco, 2004), implicating the antibody in resistance to HIV infection.

Several vaccine approaches have been evaluated in non-human primates for the ability to elicit viral-specific IgA antibodies at genital/rectal sites. These have included tonsillar immunizations with replication-defective SIV (Vagenas et al., 2009), administration of DNA vaccines intranasally or rectally, followed by boosting with MVA recombinants (Bertley et al., 2004; Wang et al., 2004), intradermal or intramuscular administrations of DNA vaccines together with GM-CSF DNA or CCL27 DNA as adjuvants (Lai et al., 2007; Kraynyak et al., 2010) vaginal delivery of trimeric HIV envelope together with Carbopol gel (Cranage et al., 2011), upper respiratory track immunization with replication-competent Ad-recombinants followed by intramuscular boosting with envelope protein (Florese et al., 2009; Hidajat et al., 2009; Xiao et al., 2010), and intramuscular plus intranasal immunization with a gp41 subunit vaccine delivered on virosomes (Bomsel et al., 2011). These have had varying degrees of success in consistently eliciting mucosal IgA antibodies. Only a few studies, however, have investigated functionality of vaccine-elicited IgA as discussed below. Immune exclusion is difficult to assess in vitro due to the necessity for a mucus barrier, but neutralizing, ADCC, and ADCVI activities can be evaluated. Transcytosis inhibition seems especially relevant for mucosal protection. 


\subsection{Transcytosis inhibition}

HIV-1 transmission mainly occurs through exposure of mucosal surfaces to HIV-infected fluids, such as semen, cervicovaginal fluid, saliva, colostrum, and breast milk (Pope and Haase, 2003). A key entry event is translocation of virus across the epithelium. In rectal, intestinal, colonic, and endocervical mucosa, the epithelium is made up of a single layer of polarized, columnar epithelial cells with tight junctions separating the cells into the apical domain, which faces the lumen, and the basolateral domain, which faces the serosal side and the internal milieu (Bomsel, 1997). In contrast, ectocervical and vaginal epithelium is composed of pluristratified epithelial cells that lack a polarized plasma membrane and tight junctions, allowing intraepithelial dendritic cells and Langerhans cells to diffuse into the epithelium (Bomsel and Alfsen, 2003). Depending on the site of infection, several mechanisms for HIV-1 transmission across mucosal epithelia have been proposed, including columnar epithelial cell transcytosis, direct infection of epithelial cells, and dendritic/Langerhans cell transport (Bomsel \& David, 2002; Shattock et al., 2000).

The major type of HIV transcytosis is cell-associated (Bomsel \& Alfsen, 2003), generated by cell-cell contact of virally-infected cells with apical epithelial cell surfaces. It is a rapid, efficient, and nondegradative process in which virus is transported from the apical to the basolateral surface of polarized epithelial cells. Cell-free virus transcytosis is also possible but inefficient (Bobardt et al., 2007; Bomsel, 1997). Rather than fusion and infection, interactions between viral components, including gp41 (Alfsen et al., 2001), gp120 (Bobardt et al., 2007), and gp160 (Hocini et al., 1997), and host epithelial cell surface molecules, such as glycosphingolipid galactosyl-ceramide (GalCer) (Alfsen \& Bomsel, 2002; Meng et al., 2002), an important component of endocytotic "raft" membrane microdomains, the coreceptor CCR5 (Bomsel et al., 2007), and the heparin sulfate proteoglycan attachment receptor, agrin (Alfsen et al., 2005), lead to transcytosis of the virus across the epithelial barrier and its trapping by submucosal dendritic cells which disseminate it to target $\mathrm{CD} 4^{+} \mathrm{T}$ cells.

Immunoglobulin A (IgA) and immunoglobulin G (IgG) anti-HIV antibodies have been detected in nearly all external secretions. Although mucosal IgG may interfere with viral infection in tissues underlying mucosal epithelia and secondary lymphoid tissues, mucosal IgA is thought to best protect mucosal surfaces (Pope and Haase, 2003). HIV-1 entry via transcytosis in vitro can be inhibited by dimeric $\operatorname{IgA}(\mathrm{dIgA})$ isolated from HIV-1-infected subjects (Bomsel et al., 1998), secretory IgA specific for gp41 (Alfsen et al., 2001), and mucosal and serum IgA from HIV-1-exposed seronegative individuals (Devito et al., 2000). Recently, transcytosis inhibition of both SIV and SHIV by vaccine-elicited mucosal antibodies has been evaluated in pre-clinical studies in non-human primates. In rhesus macaques, mucosal priming with replication-competent Ad-HIV or SIV recombinants followed by intramuscular boosting with envelope protein elicited antibodies in rectal secretions able to inhibit SIV and SHIV transcytosis in vitro (Hidajat et al., 2009; Xiao et al., 2010). Importantly, a significant correlation between transcytosis inhibition and reduced chronic viremia was seen in the study by Xiao et al. (2010) suggesting that mucosal IgA present in the submucosa may play a role in viremia control during the course of infection. However, the strongest evidence to date for a contribution of transcytosis inhibition to vaccine-elicited protection was recently reported by Bomsel et al. (2011). Following intramuscular plus intranasal immunization with gp41 subunit immunogens on virosomes, 4 out of 5 rhesus macaques were protected from $\mathrm{SHIV}_{\mathrm{SF} 162 \mathrm{P} 3}$ acquisition following repetitive low-dose challenge, whereas all controls became infected. The protected macaques had 
gp41-specific vaginal IgA that mediated transcytosis inhibition, and vaginal IgG that had neutralizing and/or ADCC activity. Both the transcytosis inhibition and ADCC activity were significantly inversely correlated with acute viremia. Of particular interest, sera from these macaques lacked anti-HIV activity in neutralization, ADCC, and transcytosis inhibition assays, suggesting that the IgG with protective activity was locally produced. A similar suggestion was reported in the study of Xiao et al. (2010).

\section{Antibody avidity}

In addition to functionality, the overall quality of an antibody response largely determines its effectiveness. Antibody avidity, a measure of the strength of the binding interaction between an antigen with multiple antigenic determinants and multivalent antibodies (Siegrist et al., 2004), is one characteristic which contributes to efficacy. It develops in germinal centers following somatic hypermutation of immunoglobulin genes and selection of B cells for high affinity binding to antigen (Berek et al., 1991; French et al., 1989; Griffiths et al., 1984). Thus, this antibody maturation process is dependent on both time and antigen exposure. The importance of antibody avidity has been shown in studies associating low antibody avidity with poor protective efficacy of an RSV vaccine (Delgado et al., 2009). In contrast, high-avidity neutralizing (Barnett et al., 2010) and non-neutralizing (Zhao et al., 2009; Xiao et al., 2010) HIV-1 Env-specific antibodies have been inversely correlated with reduced SHIV viremia following challenge. Importantly, in the Xiao et al. (2010) study, significant correlations were seen between antibody avidity and both functional antibody activities: ADCC and ADCVI, both also correlated with reduced viremia. The results overall suggest that antibody maturation following vaccination is associated with better functional antibody activity.

\section{The role of memory $B$ cells in vaccine-mediated immunity}

A critical feature of protective humoral immunity is memory. The success of vaccination depends on the differentiation of naïve B cells into plasma cells and memory B cells. Plasma cells are terminally differentiated and continuously secrete antibody without requiring further antigenic stimulation. In contrast, memory B cells represent an important second line of immune defense that is initiated if pre-existing antibody levels are too low to prevent infection or if an invading pathogen is able to circumvent the pre-existing antibody response. Memory B cells do not actively secrete antibody but instead maintain their immunoglobulin in the membrane-bound form, which together with Iga and $\operatorname{Ig} \beta$ form the antigen-specific B cell receptor. Following exposure to the initial antigen these cells become fully activated, proliferate, and differentiate into antibody secreting cells (ASC) (Ahmed \& Gray, 1996; McHeyzer-Williams \& McHeyzer-Williams, 2005; Pierce \& Liu, 2010). Little is understood about the regulation of vaccine-induced humoral immunity. Differentiation of memory B cells into short-lived plasma cells is dependent on the presence of antigen (Dorner \& Radbruch, 2007; Cagigi, et al., 2008). In contrast, long-lived antibody responses generated by viral infections or vaccinations are not dependent on the continuous presence of memory B cells but are rather produced by long-lived plasma cells that reside in the bone marrow and do not require antigen for continued production of antibody (Dorner \& Radbruch, 2007; Radbruch et al., 2006). In fact, vaccine-induced B cell memory is maintained for more than 50 years after smallpox vaccination (Crotty et al., 2003), whereas antibody 
responses to tetanus toxoid and diphtheria vaccines have half-lives of 11 and 19 years, respectively (Amanna et al., 2007).

Memory B cell and serum antibody levels do not always correlate. This lack of correlation implies that the serum antibody level is maintained by long-lived plasma cells in the bone marrow and not by memory B cells circulating in the blood. However, in one of the first studies to examine the frequency of specific memory B cells in humans (Bonsignori et al., 2009), plasma antibody and memory B cell responses to HIV-1 envelope were compared in a group of chronic HIV-1 infected individuals and in volunteers vaccinated in the VAX004 clinical trial (Gilbert et al., 2005). A significant correlation between blood anti-Env memory B cells levels and plasma anti-Env antibody titers was found in both chronic HIV-1 infection and after vaccination with rgp120, suggesting that plasma antibody was maintained predominantly by short-lived memory B cells. Additionally, the half-life of anti-Env antibodies was shorter than those for influenza and tetanus toxoid, demonstrating that the HIV-1 envelope does not elicit long-lived B cell memory to the degree of other antigens. This outcome is not surprising for the HIV-infected cohort, as B-cell dysfunction, including loss of memory B cell subsets has been well-documented in HIV and SIV infection (Cagigi et al., 2008; Kuhrt et al., 2010a; Shen \& Tomaras, 2011). However, the reasons for impaired memory induction in vaccinees is not well understood, and may include immune suppression due to binding of gp120 to CD4 or binding of carbohydrates to mannose receptors on dendritic cells and B cells (Bonsignori et al., 2009).

SIV and SHIV non-human primate models have been very valuable in HIV vaccine development. Human memory B cells have been extensively studied (Bonsignori et al., 2009; Crotty et al., 2004; Bernasconi et al., 2002), but only recently have rhesus macaque memory B cell studies been undertaken (Douagi et al., 2010; Kuhrt et al., 2010). We have recently shown induction of SIV and HIV Env-specific IgG and IgA ASC in rhesus macaques following priming with replicating Ad-SIV or HIV recombinants and boosting with SIV or HIV envelope protein (Brocca-Cofano et al., 2011). Env-specific IgG and IgA specific activities were correlated with several antibody activities, including ADCC, ADCVI, and/or transcytosis inhibition, indicating that maturation of antibody responses is critical for improved functionality. Further, IgG and IgA memory B cells post challenge were inversely correlated with chronic viremia indicating that vaccine-induced memory B cells were recalled and influenced disease outcome. That memory B cells should exhibit a protective role is not surprising in view of the reported association between loss of memory B cells and rapid disease progression in both HIV and SIV infection (Titanji et al., 2006; Titanji et al., 2010). Our induction of strong anti-envelope memory B cell responses by vaccination (Brocca-Cofano et al., 2011) may reflect use of a replicating vector to prime immune responses followed by envelope boosting. The combined approach may have provided both the antigen persistence and time necessary to allow antibody maturation.

\section{Conclusion}

Antibodies are key to host defense and critical for HIV vaccine design. Antibodies that recognize conserved epitopes and broadly neutralize virus can prevent infection. Once infection has occurred, other antibodies that interact with viral antigens expressed on the infected cell surface are needed to eliminate initial foci, or control subsequent systemic spread of the virus. Fc receptor-bearing effector cells, such as NK cells, can mediate killing of infected cells by ADCC and/or ADCVI activities. The latter can also inhibit viral 
replication. Mucosal antibodies that block viral entry through mechanisms such as transcytosis inhibition help control viral transmission and spread. As summarized here, maturation of vaccine-induced antibody responses is necessary for optimal function. Both antibody avidity and memory are directly associated with functional activity and control of viremia. An HIV/AIDS vaccine should be able to induce both cellular and humoral immunity. Regarding the latter, the success of a vaccine will depend on stimulating the production of mature high-titered antibodies with sufficiently broad reactivity to protect against HIV and SIV encounters. The path to induction of protective anti-envelope antibodies will come from understanding the B cell regulatory pathway of specific antibody production and from design of optimal immunogens. Coordination between human vaccine clinical trials and nonhuman primate vaccine challenge studies is essential to advance new vaccine concepts and accelerate the pace of HIV-1 vaccine efficacy trials.

\section{Acknowledgement}

This work was supported by the Intramural Research Program of the National Institutes of Health, National Cancer Institute.

\section{References}

Aasa-Chapman, M.M., Hayman, A., Newton, P., Cornforth, D., Williams, I., Borrow, P., Balfe, P., \& McKnight, A. (2004). Development of the antibody response in acute HIV-1 infection. AIDS 18, 371-381.

Ahmad, A., \& Menezes, J. (1996). Antibody-dependent cellular cytotoxicity in HIV infections. FASEB Journal 10, 258-266.

Ahmed, R., \& Gray, D. (1996). Immunological memory and protective immunity: understanding their relation. Science 272, 54-60.

Alfsen, A. \& Bomsel, M. (2002). HIV-1 gp41 envelope residues 650-685 exposed on native virus act as a lectin to bind epithelial cell galactosyl ceramide. Journal of Biological Chemistry 277, 25649-25659.

Alfsen, A., Iniguez, P., Bouguyon, E., \& Bomsel, M. (2001). Secretory IgA specific for a conserved epitope on gp41 envelope glycoprotein inhibits epithelial transcytosis of HIV-1. Journal of Immunology 166, 6257-6265.

Alfsen, A., Yu, H., Magerus-Chatinet, A., Schmitt, A., \& Bomsel, M. (2005). HIV-1-infected blood mononuclear cells form an integrin- and agrin-dependent viral synapse to induce efficient HIV-1 transcytosis across epithelial cell monolayer. Molecular Biology of the Cell 16, 4267-4279.

Almond, D., Kimura, T., Kong, X., Swetnam, J., Zolla-Pazner, S., \& Cardozo, T. (2010). Structural conservation predominates over sequence variability in the crown of HIV type 1's V3 loop. AIDS Research and Human Retroviruses, 26, 717-723.

Alsmadi, O., Herz, R., Murphy, E., Pinter, A., \& Tilley, S.A. (1997). A novel antibodydependent cellular cytotoxicity epitope in gp120 is identified by two monoclonal antibodies isolated from a long-term survivor of human immunodeficiency virus type 1 infection. Journal of Virology 71, 925-933.

Alsmadi, O., \& Tilley, S.A. (1998). Antibody-dependent cellular cytotoxicity directed against cells expressing human immunodeficiency virus type 1 envelope of primary or 
laboratory-adapted strains by human and chimpanzee monoclonal antibodies of different epitope specificities. Journal of Virology 72, 286-293.

Alter, G. \& Moody, A. (2010). The humoral response to HIV-1: new insights, renewed focus. The Journal of Infectious Diseases 202, S315-S322.

Amanna, I.J., Carlson, N.E., \& Slifka, M.K. (2007). Duration of humoral immunity to common viral and vaccine antigens. New England Journal of Medicine 357, 1903-1815.

Amanna, I.J., \& Slifka, M.K. (2010). Contributions of humoral and cellular immunity to vaccine-induced protection in humans. Virology 411, 206-215.

Baba, T.W., Liska, V., Hofmann-Lehmann, R., Vlasak, J., Xu, W., Ayehunie, S., Cavacini, L.A., Posner, M.R., Katinger, H., Stiegler, G., Bernacky, B.J., Rizvi T.A., Schmidt, R., Hill, L.R., Keeling, M.E., Lu, Y., Wright, J.E., Chou, T-C., \& Ruprecht, R.M. (2000). Human neutralizing monoclonal antibodies of the IgG1 subtype protect against mucosal simian-human immunodeficiency virus infection. Nature Medicine 6, 200206.

Banks, N.D., Kinsey, N., Clements, J., \& Hildreth, J.E.K. (2002). Sustained antibodydependent cell-mediated cytotoxicity (ADCC) in SIV-infected macaques correlates with delayed progression to AIDS. AIDS Research and Human Retroviruses 18, 11971205.

Barnett, S.W., Burke, B., Sun, Y., Kan, E., Legg, H., Lian, Y., Bost, K., Zhou, F., Goodsell, A., Zur Megede, J., Polo, J., Donnelly, J., Ulmer, J., Otten, G.R., Miller, C.J., Vajdy, M., \& Srivastava, I.K. (2010). Antibody-mediated protection against mucosal simianhuman immunodeficiency virus challenge of macaques immunized with alphavirus replicon particles and boosted with trimeric envelope glycoprotein in MF59 adjuvant. Journal of Virology 84, 5975-5985.

Battle-Miller, K., Eby, C.A., Landay, A.L., Cohen, M.H., Sha, B.E., \& Baum, L.L. (2002). Antibody-dependent cell-mediated cytotoxicity in cervical lavage fluids of human immunodeficiency virus type 1--infected women. Journal of Infectious Diseases 185, 439-447.

Baum, L.L., Cassutt, K.J., Knigge, K., Khattri, R., Margolick, J., Rinaldo, C., Kleeberger, C.A., Nishanian, P., Henrard, D.R., \& Phair, J. (1996). HIV-1 gp120-specific antibodydependent cell-mediated cytotoxicity correlates with rate of disease progression. Journal of Immunology 157, 2168-2173.

Benmira, S., Bhattacharya, V., \& Schmid, M.L. (2010). An effective HIV vaccine: A combination of humoral and cellular immunity? Current HIV Research 8, 441-449.

Berek, C., Berger, A., \& Apel, M. (1991). Maturation of the immune response in germinal centers. Cell 67, 1121-1129.

Bernasconi, N.L., Traggiai, E., \& Lanzavecchia, A. (2002). Maintenance of serological memory by polyclonal activation of human memory B cells. Science 298, 2199-2202.

Bertley, F.M.N., Kozlowski, P.A., Wang, S., Chappelle, J., Patel, J., Sonuyi, O., Mazzara, G., Montefiori, D., Carville, A., Mansfield, K.G., \& Aldovini, A. (2004). Control of simian/human immunodeficiency virus viremia and disease progression after IL-2augmented DNA-modified vaccinia virus Ankara nasal vaccination in nonhuman primates. Journal of Immunology 172, 3745-3757.

Binley, J.M., Clas, B., Gettie, A., Vesanen, M., Montefiori, D.C., Sawyer, L., Booth, J., Lewis, M., Marx, P.A., Bonhoeffer, S., \& Moore, J.P. (2000). Passive infusion of immune 
serum into simian immunodeficiency virus-infected rhesus macaques undergoing a rapid disease course has minimal effect on plasma viremia. Virology 270, 237-249.

Bobardt, M.D., Chatterji, U., Selvarajah, S., Van der Schueren, B., David, G., Kahn, B., \& Gallay, P.A. (2007). Cell-free human immunodeficiency virus type 1 transcytosis through primary genital epithelial cells. Journal of Virology 81, 395-405.

Bomsel, M. (1997). Transcytosis of infectious human immunodeficiency virus across a tight human epithelial cell line barrier. Nature Medicine 3, 42-47.

Bomsel, M., \& Alfsen, A. (2003). Entry of viruses through the epithelial barrier: pathogenic trickery. Nature Reviews Molecular and Cellular Biology 4, 57-68.

Bomsel, M., \& David, V. (2002). Mucosal gatekeepers: selecting HIV viruses for early infection. Nature Medicine 8, 114-116.

Bomsel, M., Heyman, M., Hocini, H., Lagaye, S., Belec, L., Dupont, C., \& Desgranges, C. (1998). Intracellular neutralization of HIV transcytosis across tight epithelial barriers by anti-HIV envelope protein dIgA or IgM. Immunity 9, 277-287.

Bomsel, M., Pastori, C., Tudor, D., Alberti, C., Garcia, S., Ferrari, D., Lazzarin, A., \& Lopalco, L. (2007). Natural mucosal antibodies reactive with first extracellular loop of CCR5 inhibit HIV-1 transport across human epithelial cells. AIDS 21:13-22.

Bomsel, M., Tudor, D., Drillet, A., Alfsen, A., Ganor, Y., Roger, M., Mouz, N., Amacker, M., Chalifour, A., Diomede, L., Devillier, G., Cong, Z., Wei, Q., Gao, H., Qin, C., Yang, G., Zurbriggen, R., Lopalco, L., \& Fleury, S. (2011). Immunization with HIV-1 gp41 subunit virosomes induces mucosal antibodies protecting nonhuman primates against vaginal SHIV challenges. Immunity 34, 269-280.

Bonsignori, M., Moody, M.A., Parks, R.J., Holl, T.M., Kelsoe, G., Hicks, C.B., Vandergrift, N., Tomaras, G.D., \& Haynes, B.F. (2009). HIV-1 envelope induces memory B cell responses that correlate with plasma antibody levels after envelope gp120 protein vaccination or HIV-1 infection. Journal of Immunology 183, 2708-2717.

Brocca-Cofano, E., McKinnon, K., Demberg, T., Venzon, D., Hidajat, R., Xiao, P., DaltabuitTest, M., Patterson, L.J., \& Robert-Guroff, M. (2011). Vaccine-elicited SIV and HIV envelope-specific IgA and IgG memory B cells in rhesus macaque peripheral blood correlate with functional antibody responses and reduced viremia. Vaccine In press.

Broliden, K., Sievers, E., Tovo, P.A., Moschese, V., Scarlatti, G., Broliden, P.A., Fundaro, C., \& Rossi, P. (1993). Antibody-dependent cellular cytotoxicity and neutralizing activity in sera of HIV-1-infected mothers and their children. Clinical and Experimental Immunology 93, 56-64.

Burton, D.R., Pyati, J., Koduri, R., Sharp, S.J., Thornton, G.B., Parren, P.W.H.I., Sawyer, L.S.W., Hendry, R.M., Dunlop, N., Nara, P.L., Lamacchia, M., Garratty, E., Stiehm, E.R., Bryson, Y.J., Cao, Y., Moore, J.P., Ho, D.D., \& Barbas, C.F., III. (1994). Efficient neutralization of primary isolates of HIV-1 by a recombinant human monoclonal antibody. Science 266, 1024-1027.

Cagigi, A., Nilsson, A., De Milito, A., \& Chiodi, F. (2008). B cell immunopathology during HIV-1 infection: lessons to learn for HIV-1 vaccine design. Vaccine 26, 3016-3025.

Chavez-Galan, L., Arenas-Del Angel, M.C., Zenteno, E., Chavez, R., \& Lascurain, R. (2009). Cell death mechanisms induced by cytotoxic lymphocytes. Cellular $\mathcal{E}$ Molecular Immunology 6, 15-25.

Chuenchitra, T., Wasi, C., Louisirirojchanakul, S., Nitayaphan, S., Sutthent, R., Cox, J.H., de Souza, M.S., Brown, A.E., Birx, D.L., \& Polonis, V.R. (2003). Longitudinal study of 
humoral immune responses in HIV type 1 subtype CRF01_AE (E)-infected Thai patients with different rates of disease progression. AIDS Research and Human Retroviruses 19, 293-305.

Chung, A.W., Rollman, E., Center, R.J., Kent, S.J., \& Stratov, I. (2009). Rapid degranulation of NK cells following activation by HIV-specific antibodies. Journal of Immunology 182, 1202-1210.

Corti, D., Langedijk, J.P., Hinz, A., Seaman, M.S., Vanzetta, F., Fernandez-Rodriguez, B.M., Silacci, C., Pinna, D., Jarrossay, D., Balla-Jhagjhoorsingh, S., Willems, B., Zekveld, M.J., Dreja, H., O'Sullivan, E., Pade, C., Orkin C., Jeffs, S.A., Montefiori, D.C., Davis, D., Weissenhorn, W., McKnight, A., Heeney, J.L., Sallusto, F., Sattentau, Q.J., Weiss, R.A., \& Lanzavecchia, A. (2010). Analysis of memory B cell responses and isolation of novel monoclonal antibodies with neutralizing breadth from HIV-1-infected individuals. PLoS One 5, e8805.

Cranage, M.P., Fraser, C.A., Cope, A., McKay, P.F., Seaman, M.S., Cole, T., Nahmoud, A.N., Hall, J., Giles, E., Voss, G., Page, M., Almond, N., \& Shattock, R.J. (2011). Antibody responses after intravaginal immunization with trimeric HIV-1 $1_{\mathrm{CN} 54}$ clade C gp140 in Carbopol gel are augmented by systemic priming or boosting with an adjuvanted formulation. Vaccine 29, 1421-1430.

Crotty, S., Aubert, R.D., Glidewell, J., \& Ahmed, R. (2004). Tracking human antigen-specific memory B cells: a sensitive and generalized ELISPOT system. Journal of Immunological Methods 286, 111-122.

Crotty, S., Felgner, P., Davies, H., Glidewell, J., Villarreal, L., \& Ahmed, R. (2003). Cutting edge: long-term $\mathrm{B}$ cell memory in humans after smallpox vaccination. Journal of Immunology 171, 4969-4973.

Dalgleish, A., Sinclair, A., Steel, M., Beatson, D., Ludlam, C., \& Habeshaw, J. (1990). Failure of ADCC to predict HIV-associated disease progression or outcome in a haemophiliac cohort. Clinical and Experimental Immunology 81, 5-10.

Delgado, M.F., Coviello, S., Monsalvo, A.C., Melendi, G.A., Hernandez, J.Z., Batalle, J.P., Diaz, L., Trento, A., Chang, H.Y., Mitzner, W., Ravetch, J., Melero, J.A., Irusta, P.M., \& Polack, F.P. (2009). Lack of antibody affinity maturation due to poor Toll-like receptor stimulation leads to enhanced respiratory syncytial virus disease. Nature Medicine 15, 34-41.

De Saint Basile, G., Menasche, G., \& Fischer, A. (2010). Molecular mechanisms of biogenesis and exocytosis of cytotoxic granules. Nature Reviews Immunology 11, 568-579.

Devito, C., Broliden, K., Kaul, R., Svensson, L., Johansen, K., Kiama., P, Kimani, J., Lopalco, L., Piconi, S., Bwayo, J.J., Plummer, F., Clerici, M., \& Hinkula, J. (2000). Mucosal and plasma IgA from HIV-1-exposed uninfected individuals inhibit HIV-1 transcytosis across human epithelial cells. Journal of Immunology 165, 5170-5176.

Doria-Rose, N.A., Klein, R.M., Daniels, M.G., O’Dell, S., Nason, M., Lagedes, A., Bhattacharya, T., Migueles, S.A., Wyatt, R.T., Korber, B.T., Mascola, J.R., \& Connors, M. (2010). Breadth of human immunodeficiency virus-specific neutralizing activity in sera: clustering analysis and association with clinical variables. Journal of Virology 84, 1631-1636.

Dorner, T. \& Radbruch, A. (2007). Antibodies and B cell memory in viral immunity. Immunity 27, 384-392. 
Douagi, I., Forsell, M.N.E., Sundling, C., O'Dell, S., Feng, Y., Dosenovic, P., Li, Y., Seder, R., Loré, K., Mascola, J.R., Wyatt, R.T., \& Hedestam, G.B.K. (2010) Influence of novel CD4 binding-defective HIV-1 envelope glycoprotein immunogens on neutralizing antibody and T-cell responses in nonhuman primates. Journal of Virology 84, 16831695.

Florese, R.H., Demberg, T., Xiao, P., Kuller, L., Larsen, K., Summers, L.E., Venzon, D., Cafaro, A., Ensoli, B., \& Robert-Guroff, M. (2009). Contribution of nonneutralizing vaccine-elicited antibody activities to improved protective efficacy in rhesus macaques immunized with Tat/Env compared with multigenic vaccines. Journal of Immunology 182, 3718-3727.

Florese, R.H., Van Rompay, K.K., Aldrich, K., Forthal, D.N., Landucci ,G., Mahalanabis, M., Haigwood, N., Venzon, D., Kalyanaraman, V.S., Marthas, M.L., \& Robert-Guroff, M. (2006). Evaluation of passively transferred, nonneutralizing antibody-dependent cellular cytotoxicity-mediating IgG in protection of neonatal rhesus macaques against oral SIVmac251 challenge. Journal of Immunology 177, 4028-4036.

Forthal, D.N., Gilbert, P.B., Landucci, G., \& Phan, T. (2007). Recombinant gp120 vaccineinduced antibodies inhibit clinical strains of HIV-1 in the presence of Fc receptorbearing effector cells and correlate inversely with HIV infection rate. Journal of Immunology 178, 6596-6603.

Forthal, D.N., \& Landucci, G. (1998). In vitro reduction of virus infectivity by antibodydependent cell-mediated immunity. Journal of Immunological Methods 220, 129-138.

Forthal, D.N., Landucci, G., Cole, K.S., Marthas, M., Becerra, J.C., \& Van Rompay, K. (2006). Rhesus macaque polyclonal and monoclonal antibodies inhibit simian immunodeficiency virus in the presence of human or autologous rhesus effector cells. Journal of Virology 80, 9217-9225.

Forthal, D.N., Landucci, G., \& Daar, E.S. (2001). Antibody from patients with acute human immunodeficiency virus (HIV) infection inhibits primary strains of HIV type 1 in the presence of natural-killer effector cells. Journal of Virology 75, 6953-6961.

Forthal, D.N., Landucci, G., \& Keenan, B. (2001a). Relationship between antibody-dependent cellular cytotoxicity, plasma HIV type 1 RNA, and CD4+ lymphocyte count. AIDS Research and Human Retroviruses 17, 553-561.

Forthal, D.N., \& Moog, C. (2009). Fc receptor-mediated antiviral antibodies. Current Opinion in HIV AIDS 4, 388-393.

French, D.L., Laskov, R., Scharff M.D. (1989). The role of somatic hypermutation in the generation of antibody diversity. Science 244, 1152-1157.

Gilbert, P.B., Peterson, M.L., Follmann, D., Hudgens, M.G., Francis, D.P., Gurwith, M., Heyward, W.L., Jobes, D.V., Popovic, V., Self, S.G., Sinangil, F., Burke, D., \& Berman, P.W. (2005). Correlation between immunologic responses to a recombinant glycoprotein 120 vaccine and incidence of HIV-1 infection in a phase 3 HIV-1 preventive vaccine trial. Journal of Infectious Diseases 191, 666-677.

Goepfert, P.A., Tomaras, G.D., Horton, H., Montefiori, D., Ferrari, G., Deers, M., Voss, G., Koutsoukos, M., Pedneault, L., Vandepapeliere, P., McElrath, M.J., Spearman, P., Fuchs, J.D., Koblin, B.A., Blattner, W.A., Frey, S., Baden, L.R., Harro, C., Evans, T., $\&$ the NIAID HIV Vaccine Trials Network. (2007). Durable HIV-1 antibody and Tcell responses elicited by an adjuvanted multi-protein recombinant vaccine in uninfected human volunteers. Vaccine 25, 510-518. 
Gomez-Roman, V.R. , Florese, R.H., Patterson, L.J., Peng, B., Venzon, D., Aldrich, K., \& Robert-Guroff, M. (2006). A simplified method for the rapid fluorometric assessment of antibody-dependent cell-mediated cytotoxicity. Journal of Immunological Methods 308, 53-67.

Gomez-Roman, V.R., Florese, R.H., Peng, B., Montefiori, D., Kalyanaraman, V.S., Venzon, D., Srivastava, I., Barnett, S.W., \& Robert-Guroff, M. (2006). An adenovirus-based HIV subtype-B prime/boost vaccine regimen elicits antibodies mediating broad antibody-dependent cellular cytotoxicity against non-subtype-B strains. Journal of Acquired Immune Deficiency Syndromes 43, 270-277.

Gomez-Roman, V.R., Patterson, L.J., Venzon, D., Liewehr, D., Aldrich, K., Florese, R., \& Robert-Guroff, M. (2005). Vaccine-elicited antibodies mediate antibody-dependent cellular cytotoxicity correlated with significantly reduced acute viremia in rhesus macaques challenged with SIVmac251. Journal of Immunology 174, 2185-2189.

Gorny, M.K., Stamatatos, L., Volsky, B., Revesz, K., Williams, C., Wang, X., Cohen, S., Staudinger, R., \& Zolla-Pazner, S. (2005). Identification of a new quaternary neutralizing epitope on human immunodeficiency virus type 1 virus particles. Journal of Virology 79, 5232-5237.

Gray, E.S., Moore, P.L., Choge, I.A., Decker, J.M., Bibollet-Ruche, F., Li, H., Leseka, N., Treurnicht, F., Mlisana, K., Shaw, G.M., Karim, S.S., Williamson, C., \& Morris, L. (2007). Neutralizing antibody responses in acute human immunodeficiency virus type 1 subtype C infection. Journal of Virology 81, 6187-6196.

Griffiths, G.M., Berek, C., Kaartinen, M., \& Milstein, C. (1984). Somatic mutation and the maturation of immune response to 2-phenyl oxazolone. Nature 312, 271-275.

Haase, A.T. (2005). Perils at mucosal front lines for HIV and SIV and their hosts. Nature Reviews Immunology 5, 783-792.

Hessell A.J., Hangartner, L., Hunter, M., Havenith, C.E.G., Beurskens, F.J., Bakker, J.M., Lanigan, C.M.S., Landucci, G., Forthal, D.N., Parren, P.W.H.I., Marx, P.A., \& Burton, D.R. (2007). Fc receptor but not complement binding is important in antibody protection against HIV. Nature 449, 101-105.

Hessell, A.J., Poignard, P., Hunter, M., Hangartner, L., Tehrani, D.M., Bleeker, W.K., Parren, P.W.H.I., Marx, P.A., \& Burton, D.R. (2009). Effective, low-titer antibody protection against low-dose repeated mucosal SHIV challenge in macaques. Nature Medicine 15, 951-955,

Hidajat, R., Xiao, P., Zhou, Q., Venzon, D., Summers, L.E., Kalyanaraman, V.S., Montefiori, D.C., \& Robert-Guroff, M. (2009). Correlation of vaccine-elicited systemic and mucosal nonneutralizing antibody activities with reduced acute viremia following intrarectal simian immunodeficiency virus SIVmac251 challenge of rhesus macaques. Journal of Virology 83, 791-801.

Hioe, C.E., Wrin, T., Seaman, M.S., Yu, X., Wood, B., Self, S., Williams, C., Gorny, M.K., \& Zolla-Pazner, S. Anti-V3 monoclonal antibodies display broad neutralizing activities against multiple HIV-1 subtypes. PLoS One 5, e10254.

Hocini, H., Belec, L., Iscaki, S., Garin, B., Pillot, J., Becquart, P., \& Bomsel, M. (1997). Highlevel ability of secretory IgA to block HIV type 1 transcytosis: contrasting secretory IgA and IgG responses to glycoprotein 160. AIDS Research and Human Retroviruses 13,1179-1185. 
Hu, S-L. \& Stamatatos, L. (2007). Prospects of HIV Env modification as an approach to HIV vaccine design. Current HIV Research 5, 507-513.

Isitman, G., Chung, A.W., Navis, M., Kent, S.J., \& Stratov, I. (2010). Pol as a target for antibody dependent cellular cytotoxicity responses in HIV-1 infection. Virology 412, 110-116.

Jiang, X., Burke, V., Totrov, M., Williams, C., Cardozo, T., Gorny, M.K., Zolla-Pazner, S., \& Kong, X. (2010). Conserved structural elements in the V3 crown of HIV-1 gp120. Nature Structural \& Molecular Biology 17, 955-962.

Karnasuta, C., Paris, R.M., Cox, J.H., Nitayaphan, S., Pitisuttithum, P., Thogncharoen, P., Brown, A.E., Gurunathan, S., Tartaglia, J., Heyward, W.L., McNeil, J.G., Birx, D.L., de Souza, M.S., \& TAVEG Thai AIDS Vaccine Evaluation Group, Thailand. (2005). Antibody-dependent cell-mediated cytotoxic responses in participants enrolled in a phase I/II ALVAC-HIV/AIDSVAX B/E prime-boost HIV-1 vaccine trial in Thailand. Vaccine 23, 2522-2529.

Korber, B., Gaschen, B., Yusim K., Thakallapally, R., Kesmir, C., \& Detours, V. (2001). Evolutionary and immunological implications of contemporary HIV-1 variation. British Medical Bulletin 58, 19-42.

Kozlowski, P.A. \& Neutra, M.R. (2003). The role of nucosal immunity in prevention of HIV transmission. Current Molecular Medicine 3, 217-228.

Kraynyak, K.A., Kutzler, M.A., Cisper, N.J., Khan, A.S., Draghia-Akli, R., Sardesal, N.Y., Lewis, M.G., Yan, J., \& Weiner, D.B. (2010). Systemic immunization with CCL27/CTACK modulates immune responses at mucosal sites in mice and macaques. Vaccine 28, 1942-1951.

Kuhrt, D., Faith, S., Hattemer, A., Leone A., Sodora, D., Picker, L., Borghesi, L., \& Cole, K.S. (2010). Naive and memory B cells in the rhesus macaque can be differentiated by surface expression of CD27 and have differential responses to CD40 ligation. Journal of Immunological Methods 363, 166-176.

Kuhrt, D., Faith, S.A., Leone, A., Rohankedkar, M., Sodora, D.L., Picker, L.J., \& Cole, K.S. (2010a). Evidence of early B-cell dysregulation in simian immunodeficiency virus infection: rapid depletion of naïve and memory B-cell subsets with delayed reconstitution of the naïve B-cell population. Journal of Virology 84, 2466-2476.

Lai, L., Vodros, D., Kozlowski, P.A., Montefiori, D.C., Wilson, R.L., Akerstrom, V.L., Chennareddi, L., Yu, T., Kannanganat, S., Ofielu, L., Villinger, F., Wyatt, L.S., Moss, B., Amara, R.R., \& Robinson, H.L. (2007). GM-CSF DNA: an adjuvant for higher avidity IgG, rectal IgA, and increased protection against the acute phase of a SHIV89.6P challenge by a DNA/MVA immunodeficiency virus vaccine. Virology 369, 153-167.

Lambotte, O., Ferrari, G., Moog, C., Yates, N..L, Liao, H-X., Parks, R.J., Hicks, C.B., Owzard, K., Tomaras, G.D., Montefiori, D.C., Haynes, B.F., \& Delfraissy, J-F. (2009). Heterogeneous neutralizing antibody and antibody-dependent cell cytotoxicity responses in HIV-1 elite controllers. AIDS 23, 897-906.

Lifson, A.R., Buchbinder, S.R., Sheppard, H.W., Mawle, A.C., Wilber, J.C., Stanley, M., Hart C.E., Hessol, N.A., \& Holmberg, S.D. (1991). Long-term human immunodeficiency virus infection in asymptomatic homosexual and bisexual men with normal CD4+ lymphocyte counts: immunologic and virologic characteristics. Journal of Infectious Diseases 163, 959-965. 
Ljunggren, K., Moschese, V., Broliden, P.A., Giaquinto, C., Quinti, I., Fenyö, E.M., Wahren, B., Rossi, P., and Jondal, M. (1990). Antibodies mediating cellular cytotoxicity and neutralization correlate with a better clinical stage in children born to human immunodeficiency virus-infected mothers. Journal of Infectious Diseases 161,198-202.

Lopalco, L. (2004). Humoral immunity in HIV-1 exposure: cause or effect of HIV resistance? Current HIV Research 2, 127-139.

Lyerly, H.K., Reed, D.L., Matthers, T.J., Langlois, A.J., Ahearne, P.A., Petteway, S.R., Jr., \& Weinhold, K.J. (1987). Anti-GP 120 antibodies from HIV seropositive individuals mediate broadly reactive anti-HIV ADCC. AIDS Research and Human Retroviruses 3, 409-422.

Mascola, J.R., D'Souza, P., Gilbert, P., Hahn, B.H., Haigwood, N.L., Morris, L., Petropoulos, C.J., Polonis, V.R., Sarzotti M., \& Montefiori, D.C. (2005). Recommendations for the design and use of standard virus panels to assess neutralizing antibody responses elicited by candidate human immunodeficiency virus type 1 vaccines. Journal of Virology 79, 10103-10107.

Mascola, J.R., Lewis, M.G., Stiegler, G., Harris, D., VanCott, T.C., Hayes, D., Louder, M.K., Brown, C.R., Sapan, C.V., Frankel S.S., Lu, Y., Robb, M.L., Katinger, H., \& Birx, D.L. (1999). Protection of macaques against pathogenic simian/human immunodeficiency virus $89.6 \mathrm{PD}$ by passive transfer of neutralizing antibodies. Journal of Virology 73, 4009-4018.

Mascola, J.R. \& Montefiori, D.C. (2010). The role of antibodies in HIV vaccines. Annual Review of Immunology 28, 412-444.

Mascola, J.R., Stiegler, G., VanCott, T.C., Katinger, H., Carpenter, C.B., Hanson, C.E., Beary, H., Hayes, D., Frankel, S.S., Birx, D.L., \& Lewis, M.G. (2000). Protection of macaques against vaginal transmission of a pathogenic HIV-1/SIV chimeric virus by passive infusion of neutralizing antibodies. Nature Medicine 5, 207-210.

McElrath, M.J. \& Haynes, B.F. (2010). Induction of immunity to human immunodeficiency virus type-1 by vaccination. Immunity $33,542-554$.

McHeyzer-Williams, L.J., \& McHeyzer-Williams, M.G. (2005). Antigen-specific memory B cell development. Annual Review of Immunology 23, 487-513.

Meng, G., Wei, X., Wu, X., Sellers, M.T., Decker, J.M., Moldoveanu, Z., Orenstein, J.M., Graham, M.F., Kappes, J.C., Mestecky, J., Shaw, G.M., \& Smith, P.D. (2002). Primary intestinal epithelial cells selectively transfer R5 HIV-1 to CCR5+ cells. Nature Medicine 8, 150-156.

Miyazawa, M., Lopalco, L., Mazzotta, F., Caputo, S.L., Veas, F., \& Clerici, M., for the ESN Study Group. (2009). The "immunologic advantage" of HIV-exposed seronegative individuals. AIDS 23, 161-175.

Muster, T., Steindl, F., Purtscher, M., Trkola, A., Klima, A., Himmler, G., Ruker, F., \& Katinger, H. (1993). A conserved neutralizing epitope on gp41 of human immunodeficiency virus type 1. Journal of Virology 67, 6642-6647.

Nag, P., Kim, J., Sapiega, V., Landay, A.L., Bremer, J.W., Mestecky, J., Reichelderfer, P., Kovacs, A., Cohn, J., Weiser, B., \& Baum, L.L. (2004). Women with cervicovaginal antibody-dependent cell-mediated cytotoxicity have lower genital HIV-1 RNA loads. Journal of Infectious Diseases 190, 1970-1978.

Nitayaphan, S., Pitisuttithum, P., Karnasuta, C., Eamsila, C., de Souza, M., Morgan, P., Polonis, V., Benenson, M., VanCott, T., Ratto-Kim, S., Kim, J., Thapinta, D., Garner, 
R., Bussaratid, V., Singharaj, P., el Habib, R., Gurunathan, S., Heyward, W., Birx, D., McNeil, J., \& Brown, A.E., for the Thai AIDS Vaccine Evaluation Group. (2004). Safety and immunogenicity of an HIV subtype B and E prime-boost vaccine combination in HIV-negative Thai adults. The Journal of Infectious Diseases 190, $702-$ 706.

Niwa, R., Natsume, A., Uehara, A., Wakitani, M., Iida, S., Uchida, K., Satoh, M., \& Shitara, K. (2005). IgG subclass-independent improvement of antibody-dependent cellular cytotoxicity by fucose removal from Asn297-linked oligosaccharides. Journal of Immunological Methods 306, 151-160.

Ojo-Amaize, E.A., Nishanian, P., Keith, D.E., Jr, Houghton, R.L., Heitjan, D.F., Fahey, J.L., \& Giorgi, J.V. (1987). Antibodies to human immunodeficiency virus in human sera induce cell-mediated lysis of human immunodeficiency virus-infected cells. Journal of Immunology 139, 2458-2463.

Parren, P.W.H.I., Marx, P.A., Hessell, A.J., Luckay, A., Harouse J., Cheng-Mayer, C., Moore, J.P., \& Burton, D.R. (2001). Antibody protect smacaques against vaginal challenge with a pathogenic R5 simian/human immunodeficiency virus at serum levels giving complete neutralization in vitro. Journal of Virology 75, 8340-8347.

Patterson, L.J., Malkevitch, N., Venzon, D., Pinczewski, J., Gómez-Román, V.R., Wang, L., Kalyanaraman, V.S., Markham, P.D., Robey, F.A., \& Robert-Guroff, M. (2004). Protection against mucosal simian immunodeficiency virus SIV(mac251) challenge by using replicating adenovirus-SIV multigene vaccine priming and subunit boosting. Journal of Virology 78, 2212-2221.

Pierce, S.K., \& Liu, W. (2010). The tipping points in the initiation of B cell signalling: how small changes make big differences. Nature Reviews Immunology 10, 767-777.

Pope, M., \& Haase, A.T. (2003). Transmission, acute HIV-1 infection and the quest for strategies to prevent infection. Nature Medicine 9, 847-852.

Radbruch, A., Muehlinghaus, G., Luger, E.O., Inamine, A., Smith, K.G., Dörner, T., \& Hiepe, F. (2006).Competence and competition: the challenge of becoming a long-lived plasma cell. Nature Reviews Immunology 6, 741-750.

Rerks-Ngarm, S., Pitisuttithum, P., Nitayaphan, S., Kaewkungwal, J., Chiu, J., Paris, R., Premsri, N., Namwat, C., de Souza, M., Adams, E., Benenson, M., Gurunathan, S., Tartaglia, J., McNeil, J.G., Francis, D.P., Stablein, D., Birx, D.L., Chunsuttiwat, S., Khamboonruang, C., Thongcharoen, P., Robb, M.L., Michael, N.L., Kunasol, P., \& Kim, J.H. for the NOPH-TAVEG Investigators. (2009). Vaccination with ALVAC and AIDSVAX to prevent HIV-1 infection in Thailand. New England Journal of Medicine 361 2209-2220.

Rook, A.H., Lane, H.C., Folks, T., McCoy, S., Alter, H., \& Fauci, A.S. (1987). Sera from HTLV-III/LAV antibody-positive individuals mediate antibody-dependent cellular cytotoxicity against HTLV-III/LAV-infected T cells. Journal of Immunology 138, 1064-1067.

Sather, D.N., Armann, J., Ching, L.K., Mavrantoni, A., Sellhorn, G., Caldwell, Z., Yu, X., Wood, B., Self, S., Kalams, S., \& Stamatatos, L. (2009). Factors associated with the development of cross-reactive neutralizing antibodies during human immunodeficiency virus type 1 infection. Journal of Virology 83, 757-769.

Sawyer, L.A., Katzenstein, D.A., Hendry, R.M., Boone, E.J., Vujcic, L.K., Williams, C.C., Zeger, S.L., Saah, A.J., Rinaldo, C.R., Jr., Phair, J.P., Giorgi, J.V., \& Quinnan, G.V., Jr. 
(1990). Possible beneficial effects of neutralizing antibodies and antibodydependent, cell-mediated cytotoxicity in human immunodeficiency virus infection. AIDS Research and Human Retroviruses 6, 341-356.

Scheid, J.F., Mouquet, H., Feldhahn, N., Seaman, M.S., Velinzon, K., Pietzsch, J., Ott, R.G., Anthony, R.M., Zebroski ,H., Hurley, A., Phogat, A., Chakrabarti, B., Li, Y., Connors, M., Pereyra ,F., Walker, B.D., Wardemann, H., Ho, D., Wyatt, R.T., Mascola, J.R., Ravetch, J.V., \& Nussenzweig, M.C. (2009). Broad diversity of neutralizing antibodies isolated from memory B cells in HIV-infected individuals. Nature 458, 636-640.

Seaman, M.S., Janes, H., Hawkins, N., Grandpre, L.E., Devoy, C., Giri, A., Coffey, R.T., Harris, L., Wood, B., Daniels, M.G., Bhattacharya, T., Lapedes, A., Polonis, V.R., McCutchan, F.E., Gilbert, P.B., Self, S.G., Korber, B.T., Montefiori, D.C., \& Mascola, J.R.. (2010). Tiered categorization of a diverse panel of HIV-1 Env pseudoviruses for assessment of neutralizing antibodies. Journal of Virology 84, 1439-1452.

Shattock, R.J., Griffin, G.E., \& Gorodeski, G.I. (2000). In vitro models of mucosal HIV transmission. Nature Medicine 6,607-608.

Shen, X., \& Tomaras, G.D. (2011). Alterations of the B-cell response by HIV-1 replication. Current HIV/AIDS Reports 8, 23-30.

Siegrist, C.A., Pihlgren, M., Tougne, C., Efler, S.M., Morris, M.L., AlAdhami, M.J., Cameron, D.W., Cooper, C.L., Heathcote, J., Davis, H.L., \& Lambert, P.H. (2004). Coadministration of $\mathrm{CpG}$ oligonucleotides enhances the late affinity maturation process of human anti-hepatitis B vaccine response. Vaccine 23, 615-622.

Simek, M.D., Rida, W., Priddy, F.H., Pung, P., Carrow, E., Laufer, D.S., Lehrman, J.K., Boaz, M., Tarragona-Fiol, T., Miiro, G., Birungi, J., Pozniak, A., McPhee, D.A., Manigart, O., Karita, E., Inwoley, A., Jaoko, W., DeHovitz, J., Bekker, L-G., Pitisuttithum, P., Paris, R., Walker, L.M., Poignard, P., Wrin, T., Fast, P.E., Burton, D.R., \& Koff, W.C. (2009). Journal of Virology 83, 7337-7348.

Stratov, I., Chung, A., \& Kent, S.J. (2008). Robust NK cell-mediated human immunodeficiency virus (HIV)-specific antibody-dependent responses in HIV infected subjects. Journal of Virology 82, 5450-5459.

Titanji, K., De Milito, A., Cagigi, A., Thorstensson, R., Grutzmeier, S., Atlas, A., Hejdeman, B., Kroon, F.P., Lopalco, L., Nilsson, A., \& Chiodi, F. (2006). Loss of memory B cells impairs maintenance of long-term serologic memory during HIV-1 infection. Blood $108,1580-1587$.

Titanji, K., Velu, V., Chennareddi, L., Vijay-Kumar, M., Gewirtz, A.T., Freeman, G.J., \& Amara, R.R. (2010). Acute depletion of activated memory B cells involves the PD-1 pathway in rapidly progressing SIV-infected macaques. Journal of Clinical Investigation 120, 3878-3890.

Tomaras, G.D., Yates, N.L., Liu, P., Qin, L., Fouda, G.G., Chavez, L.L., Decamp, A.C., Parks, R.J., Ashley, V.C., Lucas, J.T., Cohen, M., Eron, J., Hicks, C.B., Liao, H-X., Self, S.G., Landucci, G., Forthal, D.N., Weinhold, K.J., Keele, B.F., Hahn, B.H., Greenberg, M.L., Morris, L., Abdool Karim, S.S., Blattner, W.A., Montefiori, D.C., Shaw, G.M., Perelson, A.S., \& Haynes, B.F. (2008). Initial B-cell responses to transmitted human immunodeficiency virus type 1: Virion-binding immunoglobulin $\mathrm{M}(\mathrm{IgM})$ and $\operatorname{IgG}$ antibodies followed by plasma anti-gp41 antibodies with ineffective control of initial viremia. Journal of Virology 82, 12449-12463. 
Trkola, A., Purtscher, M., Muster, T., Ballaun, C., Buchacher, A., Sullivan, N., Srinivasan, K., Sodroski, J. Moore, J.P., \& Katinger, H. (1996). Human monoclonal antibody 2G12 defines a distinctive neutralization epitope on the gp120 glycoprotein of human immunodeficiency virus type 1. Journal of Virology 70, 1100-1108.

Vagenas, P., Williams, V.G., Piatak, M., Jr., Bess, J.W., Jr., Lifson, J.D., Blanchard, J.L., Gettie, A., \& Robbiani, M. (2009). Tonsillar application of AT-2 SIV affords partial protection against rectal challenge with SIVmac239. Journal of Acquired Immune Deficiency Syndromes 52, 433-442.

Volgmann, T., Klein-Struckmeier, A., \& Mohr, H. (1989). A fluorescence-based assay for quantitation of lymphokine-activated killer cell activity. Journal of Immunological Methods 119, 45-51.

Walker, L.M. \& Burton, D.R. (2010). Rational antibody-based HIV-1 vaccine design: current approaches and future directions. Current Opinion in Immunology 22, 358-366.

Walker, L.M., Phogat, S.K., Chan-Hui, P-Y., Wagner, D., Phung, P., Goss, J.L., Wrin, T., Simek, M.D., Fling, S., Mitchan, J.L., Lehrman, J.K., Priddy, F.H., Olsen, O.A., Frey, S.M., Hammond, P.W., Protocol G Principal Investigators, Kaminsky, S., Zamb, T., Moyle, M., Koff, W.C., Poignard, P., \& Burton, D.R. (2009). Broad and potent neutralizing antibodies from an African donor reveal a new HIV-1 vaccine target. Science 326, 285-289.

Wang, S., Bertley, F.M.N., Kozlowski, P.A., Herrmann, L., Manson, K., Mazzara, G., Piatak, M., Johnson, R.P., Carville, A., Mansfield, K., \& Aldovini, A. (2004). An SHIV DNA/MVA rectal vaccination in macaques provides systemic and mucosal virusspecific responses and protection against AIDS. AIDS Research and Human Retroviruses 20, 846-859.

Weinhold, K.J. (1990). Nonrestricted forms of anti-HIV-1 cytotoxicity. In: Techniques in HIV Research, Aldovini, A \& Walker, BD, pp. 187 - 199. Stockton Press, ISBN 0-93585988-8, New York.

Wilkinson, R.W., Lee-MacAry, A.E., Davies, D., Snary, D., \& Ross, E.L. (2001). Antibodydependent cell-mediated cytotoxicity: a flow cytometry-based assay using fluorophores. Journal of Immunological Methods 258, 183-191.

Wu, X., Yang, Z., Li, Y., Hogerkorp, C-M., Schief, W.R., Seaman, M.S., Zhou, T., Schmidt, S.D., Wu, L., Xu, L., Longo, N.S., McKee, K., O’Dell, S., Louder, M.K., Wycuff, D.L., Feng, Y., Nason, M., Doria-Rose, N., Connors, M., Kwong, P.D., Roederer, M., Wyatt, R.T., Nabel, G.J., \& Mascola, J.R. (2010). Rational design of envelope identifies broadly neutralizing human monoclonal antiobides to HIV-1. Science 329, 856-861.

Xiao, P., Zhao, J., Patterson, L.J., Brocca-Cofano, E., Venzon, D., Kozlowski, P.A., Hidajat, R., Demberg, T., \& Robert-Guroff, M. (2010). Multiple vaccine-elicited nonneutralizing antienvelope antibody activities contribute to protective efficacy by reducing both acute and chronic viremia following simian/human immunodeficiency virus SHIV89.6P challenge in rhesus macaques. Journal of Virology 84, 7161-7173.

Yamada, T., Watanabe, N., Nakamura, T., \& Iwamoto, A. (2004). Antibody-dependent cellular cytotoxicity via humoral immune epitope of Nef protein expressed on cell surface. Journal of Immunology 172 2401-2406.

Zhao, J., Lai, L., Amara, R.R., Montefiori, D.C., Villinger, F., Chennareddi, L., Wyatt, L.S., Moss, B., \& Robinson, H.L. (2009). Preclinical studies of human immunodeficiency 
virus/AIDS vaccines: inverse correlation between avidity of anti-Env antibodies and peak postchallenge viremia. Journal of Virology 83, 4102-4111.

Zolla-Pazner, S. \& Cardozo, T. (2010). Structure-function relationships of HIV-1 envelope sequence-variable regions refocus vaccine design. Nature Reviews Immunology 10, 527-535.

Zwick, M.B., Labrijn, A.F., Wang, M., Spenlehauer, C., Saphire, E.O., Binley, J.M., Moore, J.P., Stiegler, G., Katinger, H., Burton, D.R., \& Parren, P.W.H.I. (2001). Broadly neutralizing antibodies targeted to the membrane-proximal external region of human immunodeficiency virus type 1 glycoprotein gp41. Journal of Virology 75, 10892-10905. 


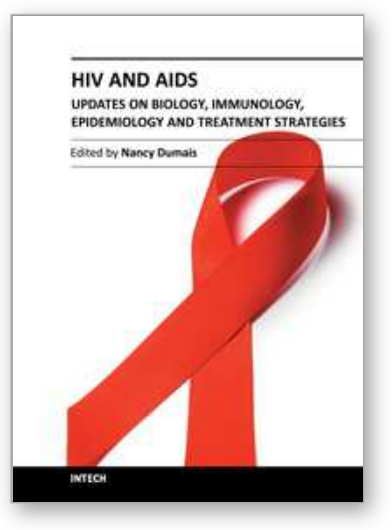

\section{HIV and AIDS - Updates on Biology, Immunology, Epidemiology and Treatment Strategies}

Edited by Dr. Nancy Dumais

ISBN 978-953-307-665-2

Hard cover, 694 pages

Publisher InTech

Published online 26, October, 2011

Published in print edition October, 2011

The continuing AIDS pandemic reminds us that despite the unrelenting quest for knowledge since the early 1980s, we have much to learn about HIV and AIDS. This terrible syndrome represents one of the greatest challenges for science and medicine. The purpose of this book is to aid clinicians, provide a source of inspiration for researchers, and serve as a guide for graduate students in their continued search for a cure of HIV. The first part of this book, â€œFrom the laboratory to the clinic,â€ and the second part, â€œFrom the clinic to the patients,â€ represent the unique but intertwined mission of this work: to provide basic and clinical knowledge on HIV/AIDS.

\section{How to reference}

In order to correctly reference this scholarly work, feel free to copy and paste the following:

Egidio Brocca-Cofano, Peng Xiao and Marjorie Robert-Guroff (2011). HIV Envelope-Specific Antibody and Vaccine Efficacy, HIV and AIDS - Updates on Biology, Immunology, Epidemiology and Treatment Strategies, Dr. Nancy Dumais (Ed.), ISBN: 978-953-307-665-2, InTech, Available from:

http://www.intechopen.com/books/hiv-and-aids-updates-on-biology-immunology-epidemiology-and-treatmentstrategies/hiv-envelope-specific-antibody-and-vaccine-efficacy

\section{INTECH}

open science | open minds

\section{InTech Europe}

University Campus STeP Ri

Slavka Krautzeka 83/A

51000 Rijeka, Croatia

Phone: +385 (51) 770447

Fax: +385 (51) 686166

www.intechopen.com

\section{InTech China}

Unit 405, Office Block, Hotel Equatorial Shanghai

No.65, Yan An Road (West), Shanghai, 200040, China

中国上海市延安西路65号上海国际贵都大饭店办公楼 405 单元

Phone: +86-21-62489820

Fax: +86-21-62489821 
(C) 2011 The Author(s). Licensee IntechOpen. This is an open access article distributed under the terms of the Creative Commons Attribution 3.0 License, which permits unrestricted use, distribution, and reproduction in any medium, provided the original work is properly cited. 